In deze rubriek staat de methode van participerende observatie centraal. In het verleden hebben onderzoekers die het spoor van Malinowski volgden, steeds geschreven over hun ervaringen met deze methode, over de voordelen die deze opleverde en over de obstakels die erdoor werden opgeworpen. Hun bijdragen bieden interessante etnografische inzichten, maar het laat zich aanzien dat hun bevindingen in grote lijnen overeenkomen. lets meer controverse kan de rubriek interessanter maken. Daarom een nieuwe insteek, die de auteurs vraagt aandacht te besteden aan het nut van en de noodzaak tot participeren. Redacteur voor deze rubriek is Frank van Gemert: f.vangemert@rechten.vu.nl.

\title{
Observaties bij het journaal
}

\section{Liesbeth Hermans}

\section{Binnenkomst op de redactie}

Het is al weer een aantal jaren geleden dat ik als onderzoeker binnenstapte bij de nieuwsredactie van het NOS-journaal in Hilversum. Ik kwam in een voor mij volledig onbekende professionele wereld terecht. Zelf ben ik geen journalist, van de beroepspraktijk die ik ging onderzoeken wist ik niets uit eigen ervaring. Uiteraard had ik mij ter oriëntatie wel van tevoren ingelezen en voerde ik een aantal gesprekken met professionals uit het veld.

Er was sprake van een open onderzoekssituatie. Alle journalisten hadden een interne memo ontvangen waarin was medegedeeld dat er enige weken een onderzoeker van de universiteit van Nijmegen zou rondlopen. De journalisten reageerden heel wisselend op mijn aanwezigheid. Sommigen waren belangstellend, vroegen wat ik precies kwam doen en hadden al meteen allerlei opmerkingen en tips. Anderen waren wat negatiever en makkten cynische opmerkingen over wetenschappelijk onderzoek en het nut daarvan. Toch heb ik weinig echte weerstand ondervonden. Ik had toegang tot vrijwel alles wat er op de redactie gebeurde (inclusief vergaderingen). Ook kon ik gebruikmaken van het interne computersysteem. De meeste journalisten waren heel welwillend om mijn vragen te beantwoorden en mij dingen te laten zien.

In het begin vonden sommige journalisten het vreemd dat ik hele dagen rondliep en her en der wat vragen stelde. In het bijzonder mijn ijverige schrijven in het grote notitieblok dat ik aanvankelijk overal bij me had, wekte enige argwaan. Men wilde weten wat ik noteerde, hoe specifiek ik notities maakte en wie die notities te lezen kregen. Dat heeft me snel doen besluiten om minder opvallend en in een kleiner boekje mijn notities te maken. Belangstellende vragen leverden vaak interessante gesprekken op. Journalisten kwamen met allerlei tips en ideeën waar ik me in het onderzoek op zou kunnen richten. Deze aanwijzingen heb ik uiteraard meegenomen in het onderzoek. 


\section{Hoe ontstaat de televisiewerkelijkheid?}

Deze casestudy was een explorerend onderzoek, het doel was het beroepsmatige handelen van journalisten te beschrijven en te expliciteren. In eerste instantie stond de vraag centraal welke betekenisschema's ten grondslag liggen aan beslissingen die journalisten nemen in hun werk. Vragen waren bijvoorbeeld gericht op professionele overwegingen zoals beroepsopvattingen, journalistieke criteria voor nieuwsselectie en het publieksbeeld.

Het oorspronkelijke doel van mijn observatieperiode was om, voorafgaand aan de geplande interviews, meer zicht te krijgen op het te onderzoeken beroepsveld. Het bleek echter al snel dat de omstandigheden op de redactie een belangrijke situationele context vormden die men moet kennen om de processen binnen de nieuwsorganisatie te kunnen begrijpen. Daarom is het onderzoek uitgebreid en zijn als eerste de nieuwsproductieprocessen beschreven die leiden tot de constructie van de werkelijkheid in de journaals.

Naast de observaties zijn met dertig journalisten diepte-interviews gehouden. Voor een belangrijk deel vulden de data die ik verkreeg via de observaties en via de interviews, elkaar aan. Observaties leerden me dat de vragen in de interviews veel concreter en duidelijker gesteld konden worden. Zo werden bij vragen over beslissingen waarom bepaalde gebeurtenissen wel en andere niet in het journaal te zien waren, in de interviews veelvuldig journalistieke nieuwswaarden als criteria genoemd. Uit de observaties werd echter duidelijk dat praktische zaken als productieschema, het dagelijkse nieuwsaanbod en beschikbaarheid van beeldmateriaal een belangrijke rol speelden in dit proces (Hermans, 2000). De omstandigheden op de redactie bleken door de journalisten als vanzelfsprekend te worden ervaren, wat kan verklaren waarom ze in eerste instantie niet werden genoemd. Pas bij het doorvragen aan de hand van concrete situaties kwamen deze omstandigheden aan de orde en gaven journalisten aan hoe ze daar tegenover stonden. Zonder de observaties was het niet mogelijk geweest om de patronen in het productieproces zo nauwkeurig te beschrijven en te achterhalen hoe, waarom en door wie beslissingen op de nieuwsredactie werden genomen.

Journalistieke opvattingen, die door de beroepsgroep als wenselijk en ideologisch worden beschouwd, bleken maar voor een deel hun dagelijkse handelen te sturen. De praktische omstandigheden op de redactie waren vaak meer bepalend voor het uiteindelijke nieuwsproduct.

Er is voor gekozen om gedurende de gehele onderzoeksperiode van drie maanden zo veel mogelijk op de redactie aanwezig te zijn. Vooral de mogelijkheid om als onderzoeker flexibel te zijn zorgde ervoor dat veel specifieke informatie toegankelijk werd. Onverwachtse gebeurtenissen die opvielen omdat ze afweken van de normale dagelijkse procedures, konden intensief worden gevolgd.

\section{Actief observeren}

De observaties gaven mij inzicht in de dagelijkse gang van zaken binnen de nieuwsorganisatie. Als onderzoeker kreeg ik daarmee zicht op de formele, maar ook de informele 
processen die plaatsvonden op de redactie. Het feit dat er een onderzoeker aanwezig was die steeds vragen stelde, zorgde ervoor dat journalisten zelf ook bewuster over dingen gingen nadenken. Dat heeft zeker invloed gehad op de data. Het gebeurde bijvoorbeeld dat journalisten mij zelf attendeerden op interessante gebeurtenissen of mij adviseerden met bepaalde sleutelfiguren te gaan praten. Ik heb in dit onderzoek geparticipeerd, zij het niet als journalist. Een dergelijke rol was niet nodig om een insiders view te krijgen en zou zelfs belemmerend hebben gewerkt. De flexibiliteit van de onderzoeker zou enorm zijn afgenomen en de focus zou dan zijn komen te liggen op het eigen functioneren als journalist.

De vragen ter verduidelijking van observaties, de informele gesprekken en de interviews met journalisten gaven inzicht in de achtergronden en motieven waarom beslissingen werden genomen. Daarbij bleek er een verschil te bestaan tussen de journalisten die daadwerkelijk de items maakten en de leidinggevende en coördinerende journalisten. Deze laatste groep journalisten was niet meer bezig met hoe over een onderwerp werd bericht, maar voornamelijk met zaken als tijdsplanning, snelheid en concurrentie. Zo was er een journalist die boos werd, omdat zijn met zorg in elkaar gezette item vlak voor de uitzending voor de helft in tijd moest worden teruggebracht. De eindredacteur besliste dat zonder overleg met de betreffende journalist en zonder naar de inhoud te hebben gekeken. Bij deze beslissing bleken geen journalistieke maar alleen praktische afwegingen een rol te spelen.

Dit soort zaken laat zien dat journalisten werkzaam in de verschillende lagen van de hiërarchische structuur uiteenlopende belangen hadden. Aan de beslissingen die werden genomen, lagen dus ook verschillende motieven ten grondslag. Journalisten met een hogere functie op de redactie bepaalden welke gebeurtenissen aan bod kwamen in het journaal. Zij hielden zich niet bezig met de inhoudelijke kant van het onderwerp. Dit inzicht was essentieel om bij de interpretaties van bepaalde data aan te kunnen sluiten bij de belevingswereld van de journalisten.

\section{Literatuur}

Hermans, L. (2000). Beroepsmatig handelen van journalisten. Een kwalitatief onderzoek bij een televisienieuwsredactie. Thela Thesis. 